\title{
Animal Welfare and Pig Factory Farming in Ontario, Canada (1950s - Present)
}

\author{
Miguel Mundstock Xavier de Carvalho \\ Federal University of Southern Frontier (UFFS) \\ Graduate Program in Agroecology and Sustainable Rural Development (PPGADR), Graduate \\ Program in History (PPGH), Campus Laranjeiras do Sul, Paraná, Brazil. \\ E-mail: miguelmxdecarvalho@gmail.com
}

Received: Aug. 28, 2020

doi:10.5296/jas.v8i4.17594
Accepted: Oct. 9, 2020

Published: Oct. 15, 2020

URL: https://doi.org/10.5296/jas.v8i4.17594

\begin{abstract}
This article explores the inception and development of pig factory farming in Ontario, Canada, since the 1950s to date, focusing on animal welfare dimensions. The study showed that although the term "animal welfare" was not well-known until the 1980s, discussions on cruelty and abnormal animal behaviour begun in the early days of factory farms. The article also delves into tensions between the humane movement and the agribusiness sector in Ontario. The article further sheds light on the social context that eventually led to an alliance in support of a conservative, incomplete notion of animal welfare between these former opponents. The article posits that as opposed to supporting the abolition of factory farming, the concept of animal welfare became central to implementing limited reforms in factory farming to convince the public and to marginalize discordant voices while concurrently expanding pig and other animal production worldwide.
\end{abstract}

Keywords: factory farm, animal welfare, pig, Ontario

\section{Introduction}

This article discusses the history of factory farms, focusing on the dimension of animal welfare which is a relatively unexplored aspect of this debate. Animal welfare refers to both of two things: 1) a social movement that has its roots in the $18^{\text {th }}$ century; and 2) an objective scientific philosophical assessment of animals' conditions. Pigs form a suitable animal population for a case study as they have been recognized as a domestic animal species that is quite similar to human beings for a long time. This implies that pigs and human beings share many physiological and psychological features - a comparative element that is central to debates around animal welfare. As Peter Singer (2011, p. IX) stated, "to prohibit any 
cross-species comparisons would be philosophically indefensible", and a barrier to overcoming speciecism.

This article that focuses on Ontario, a region in North America suitable to investigate factory farming as a global phenomenon, draws on extensive primary sources of data (agricultural censuses, trade magazines, government reports and the humane movement documents). In particular, this Canadian province is a suitable location from which we can understand the origin and the future of factory farms as well as the evolution of the concepts of animal welfare and rights.

The historiography of pigs in factory farms and other contexts has recently been expanded, as noted by Sam White in his book review of Mark Essig's Lesser Beasts, published in 2015 (White, 2016; Essig, 2015). This book is currently one of the most complete accounts about pigs. However, its' broad scope and popular style superficially addresses only the most recent developments in swine husbandry, and insufficient attention is directed to a critical discussion around animal welfare issues. Other relevant scholarly historical works about pigs include a few books and a number of loosely connected articles and book chapters (Mizelle, 2011; Albarella, Dobney \& Ervynck, 2007; Wiseman, 2000; Woods, 2012; Anderson, 2009; Finlay, 2004; Thompson, 2000; White, 2011; Mayda, 2004; White, Dalrymple \& Hume, 2007; Brisson, 2016).

At first glance, the precise origins of factory farms in Ontario and elsewhere are not as clear. The factory farm model started with the chicken industry, focused on a smaller animal that is easier to control and breed in an industrial system (Boyd, 2001; Horowitz, 2004). Through analysing agricultural census data, a pattern of larger herds of pigs were first seen in Ontario around the 1950s and early 1960s (Statistics Canada, 1961). The average number of pigs per farm (approximately 30 pigs per farm in 1961) increased to 695 in 2001 and 1,208 in 2011. Although useful to this analysis, this average number is conceals significant inequalities between farms and obscures the fact that the bulk of pig production was and has been concentrated in the hands of very few producers. From 1961 to 2011, the total number of pigs in Ontario increased from 1,686,000 to 3,088,000, conversely, the numbers of pig farms decreased from 56,378 to 2,556 (White, Dalrymple \& Hume, 2007, p. 2-17; Brisson, 2016, p. 9).

This emerging trend of larger herds owned by very few producers was not only a quantitative shift but also a qualitative shift accompanied by high-density animal confinement. These confinement operations were in turn facilitated by a set of key scientific and technological innovations that allowed pigs to survive in a highly artificial environment. This environment included antibiotics and other drugs, animal feeds, equipment, installations and new varieties of corn and soybeans that were better adapted to the climatic conditions of Ontario. Although other scholars have delved into the adoption of these technological innovations, limited scholarly attention has been directed to the relationship between these technologies and pig welfare in a historical perspective (Mayda, 2004; Finlay, 2004; White, Dalrymple \& Hume, 2007; Bowley, 2013; Keddie \& Wandel, 2001). 


\section{Hog Production Magazine and the Welfare of the Pigs}

One important source of information on the qualitative shifts in pig husbandry in Ontario, that ranges from backyard or free-range pig husbandry to a factory farm model, is the magazine Hog Production, launched in 1965 and last published in 1974. Through the national pages of the magazine, we found many aspects of and transformations in pig husbandry in Ontario. Although the term "animal welfare" does not appear in the magazine's pages, the magazine published many discussions on the "disorders of behaviour" or "stress" that pigs experienced under the new production model. Other changes that affected pig welfare can be inferred from the technologies and practices being introduced.

One of the most obvious changes that have affected the quality of life of pigs is the emergence of confinement, a central feature of the factory farm. In a business environment characterized by very tight profit margins, the highest possible density of pigs per square meter was considered a good management practice. This was due to the heavy financial investment required by farmers for building and equipment. In 1967, Hog Production told its readers that the researcher R. J. Curtis conducted experiments at the Canada Department of Agriculture's Research Station, in Fredericton, New Brunswick and concluded that, "five square feet of floor space is enough room for a pig when it is fed to market weight, in pens of eight pigs or more". In addition, he found that "severe lameness may develop in pigs weighing more than 125 pounds when four or fewer pigs are allowed only five square feet of space floor (Hog Production, 1967, October)." In the July 1968 issue, S. M. Stewart from the Ontario Hydro discussed the problem faced in ventilating barns, he stated, "just a few years ago, we were talking of 12 square feet of area per hog and today we are down into the 8 square foot and less (Stewart, 1968, p.12)." In the June 1970 issue, an article titled "How much space" mentioned that pig's space requirements had considerably changed. The article also pointed out the following recent transformations:

Years ago, hogs were raised mostly in the summer months and confined to an outside pig pen or perhaps a small shelter. The space allotted was usually about 12 to 20 square feet per animal. If the hogs were allowed to run at large in a pasture, up to 50 or more square feet per animal was not uncommon. In the modern hog barn a sow and litter confined to a farrowing crate has about 35 square feet. (...) For finishing hogs to market weight of about 200 pounds, hog producers find that 10 to 12 hogs can be housed in an average pen of about 5 feet by 15 feet which at market weight allows 6 to 8 square feet per animal (Hog Production, 1970, June, p. 14).

Although such high pig population densities in factory farms made sense economically, it was sporadically blamed for promoting a herd's disease susceptibility as well as for "disorders of behaviour" and their effects, like stress, ulcers and tail biting, in Hog Production. Concerns about these welfare issues were mainly related to the potential and real economic losses that they entailed, but in some rare instances they also conveyed genuine concern about the fate of the pigs, or the notion that the scientific approach to pig husbandry had gone too far. For example, in a 1967 article titled "stress", presented at the Guelph Swine Conference, Dr. S. C. 
Tanner stated:

I am not suggesting that we are stretching the pig beyond reasonable limits yet. You must agree however, that there is a tendency in today's "scientific era" to regard the pig more as a machine than as a live animal. By attempting to produce more meat in shorter time with less feed, we are encountering dangers which are directly related to altered metabolism or "rate of life". Many conditions are now seen which were relatively unknown at one time. I think we have to look for a balance between our scientific methods and mother nature (Tanner, 1967).

One animal welfare-related technology that attracted considerable attention in $\mathrm{Hog}$ Production is the introduction of collar use for sows. The collar was used to tie the sow to the crates so as to prevent fighting and cut feeding costs by restricting the animal's movements. This practice commenced in 1967 when a farmer (used to exemplify other farmers) patented a sow collar. Despite clear signs that this was a very cruel way of dealing with sows, the device was considered part a "modern way" of rearing sows. One farmer raised doubts about the device by voicing concerns about both the sows' discomfort and reduced economic performance (Hog Production, 1967, July, p. 3; Alderson, 1968, p. 12). In response to this, one month later, another writer claimed that the collar was endorsed by a swine specialist of the Ontario Department of Agriculture and Food named J. G. Norrish. Years later, in the January 1972 issue of the magazine, George and Robert Robson, a father and son in charge of managing the Shur- Gain Research Farm wrote that: "there's no real problem in tying sows" (Robson \& Robson, 1972).

A different animal welfare problem related to the factory farm model that was discussed in the pages of the Hog Production was frequent ulcers in swine. In 1967, two American swine specialists from Purdue University stated "the incidence of gastric ulcers in swine appears to have increased from almost nothing to a suspected high of 20 percent within past 5 to 7 years (Perry \& Picket, 1967, p. 10)." However, another specialist from the University of Wisconsin named Gustav Bohstedt considered that this increase in incidence was "possibly because more attention is paid to that part of the viscera in packing plants than a generation or two ago." The same specialist, stated that, "no clear cause or preventive has been discovered. Ulcers remain a baffling problem." In the same article, he also mentioned that the confinement environment undoubtedly created a "stress factor" (Bohstedt, 1970).

Additionally, tail biting was brought up in the magazine's pages as another animal welfare issue. An October 1967 article exposed the problem:

Bare floors, overcrowding, not enough feeders or water space, and poor traffic flow around the pen all create "stress" situations. And stress is what's blamed for the tail-biting problem that seems to be showing up more and more in otherwise healthy herds. Tail-biting used to be blamed on anemic pigs. This was before we had modern rations. Now either through boredom or discomfort, a pig takes it out on something. And the closest and most accessible item is his penmate's tail (Hog Production, 1967, October). 
The proposed solution to this problem was to dock young piglets' tails so as to prevent tail biting and its' subsequent risks of infection and disease. Based on these examples, numerous new problems were being discussed in the late 1960s and early 1970s. Because factory farming was a recent phenomenon in Ontario, like the agribusiness sector in general, people were still adapting to the new situation, including debates and changes in animal welfare issues. These examples give us a small glimpse into the massive scale of pig suffering and deaths in the then historical context of factory farms.

\section{The Ontario Humane Society and the factory Farms}

The history of protests against industrial livestock production goes back as far as the history of factory farming. One book that has received lots of praise from researchers funded by agribusiness corporations that profit from factory farming, among other people, is the Animal Machines: the new factory farming industry (1964), authored by the vegetarian quaker Ruth Harrison with a preface written by Rachel Carson. This book serialized in the British press, attracted considerable public and government attention in the UK and helped to inspire the writing of another influential book on the animal welfare/rights movement; Animal Liberation, in 1975 by Peter Singer (Woods, 2011; Preece, 2008, p. 299; Harrison, 1964; Singer, 1975).

Like other places, in Ontario the issues raised in Animal Machines and contemporary transformations in animal husbandry were emerging as issues of public concern. In June 1965, an influential leader of the provincial animal welfare (humane) movement, T. I. Hughes, wrote an editorial in the magazine Animal's Voice, published by the Ontario Humane Society (OHS) titled, "Farm or Factory?" Hughes argued that was it not only the farmers' burden to drive change in farming, but consumers should also take responsibility for farming practices. He urged:

Farmers have every right to the same standard of living as any other section of the community. They have the right to expect the same return for their capital investment as any other private businessman. But this can only be achieved at the expense of the animal if the consumer insists on buying and being able to buy, animal products at low prices. Caught in the middle, the farmer can only resort to "factory farming" to stay in business. But what of the animal or bird? How far are we, the general public, prepared to let the farmer go to convert a living animal into an item on the production line of a modern farm factory? (Hughes, 1965, p. 2)

Not only was the OHS interested in general aspects of factory farms, the society also looked into specific issues involving pigs; for instance the mention below found in the Society's Annual Report of 1966-67:

Our inspectors continued to be alerted for evidence of intensive farming practices being introduced to Ontario. One example which has been uncovered is the practice of tethering hogs by the neck. This practice has led to a large number of sows suffering various degrees of neck wounds. Every indication at 
the moment is that the Criminal Code is inadequate to deal with this abuse of animals and it is anticipated that some form of Provincial regulation will be necessary (Ontario Humane Society, 1966a).

In line with what Ruth Harrison proposed for the British context, the OHS advocated for legal reform to address the cruel practices that were embodied in intensive farming (Harrison, 2013, p. 202). Although these and other objections were mobilised by the OHS in the following years, OHS did not set out to confront the practice of animal agriculture or factory farming, but aimed to find ways of avoiding extreme animal suffering. Excluding sporadic advertisements by the Toronto Vegetarian Association founded in 1945, vegetarianism as a dietary practice or in protest against factory farming was never documented in the society's documents. This conservative approach was aligned to the animal welfare tradition in Ontario and Canada since the $19^{\text {th }}$ century. In this period, part of the elite had been interested in reforming social practices without deeply questioning society's economic and power structures (Ingram, 2013).

One example of this conservative approach to seriously cruel practices involving animals, that has not been critically analyzed is the concept of "humane slaughter" and how the OHS addressed it. In its' 1968-69 annual report, OHS expressed concern about whether or not the Department of Agriculture of Ontario was enforcing recent legislation on slaughterhouses (i.e. the humane slaughter laws, 1964). The report pointed out that "recently a Kitchener firm has developed a method of rendering hogs unconscious by electricity". The OHS also purchased equipment to perform the "humane slaughter" of poultry for use in demonstrations to trade and local agricultural officials as the legislation did not extend to poultry (Ontario Humane Society, 1968, p. 20, 21). All these actions seemed to contradict the mission of an organization dedicated to protecting animals. Although painlessly killing animals is no doubt better than killing with no concern for pain, it does not automatically turn the slaughtering process "humane", ethical or cruelty-free. Indeed, it is challenging to attempt to define any kind of slaughter of healthy and young animals as "humane" (Visak, 2011; DeGrazia, 2009; Matheny \& Chan, 2005). Another example related to pig farming that shows how the OHS popularized the concept of "humaneness" is its' mention in the 1968-69 Annual Report where it stated that the "tethering of hogs continues to be increasingly common agricultural practice, although we have been able to encourage the development of a humane collar for this purpose (Ontario Humane Society, 1968, p. 20)." These misleading uses of the adjective "humane" is instructive in understanding that this concept, far from being clear or neutral, was forged in a political field as a result of social struggles dating back to the $19^{\text {th }}$ century and more recently as a results of fights between the OHS and the Department of Agriculture (MacLachlan, 2008).

Despite this conservative approach to the concept of "humaneness", farmers and the Department of Agriculture were concerned about possible interference in factory farm practices from society. In fact, the OHS's intention to promote more robust legislation to protect animals was successfully counter-attacked by the Department of Agriculture. In 1969, the Department of Agriculture passed legislation (Bill 74) restricting the powers of OHS inspectors to audit cruel practices happening on farms: "It is the opinion of the Ontario 
Humane Society that the Act in its present form would make it impossible for the society to effectively enforce the laws that protect animals (Ontario Humane Society, 1969, p. 9)." This was a serious blow to the OHS's ability to directly act against the consolidation of factory farming practices. Based on this, it is comprehensible that the 1975 Annual Report stated "there is little doubt the general public have more faith in the Ontario Humane Society than in the Department of Agriculture to take the action necessary to protect animals (Ontario Humane Society, 1975, p. 13)". As regards humane slaughter, according to the OHS report,

government Inspectors responsible for enforcing the Humane Slaughter laws have failed in all the years that the Act has been in force to find one single infringement of the Act. Not a single charge of any kind has ever been laid against a slaughterhouse in Ontario! (Ontario Humane Society, 1975, p. 12)

The OHS documents show that, following this backlash, the only pigs seized on grounds of cruelty were those involved in cases where their rearers were not farmers but were urbanites owning small properties with rustic barns where animals were simply abandoned to starve or left untreated when they got sick (Ontario Humane Society, 1977, p. 23). Conversely, the cruel and now normal practices involving thousands of pigs and poultry in the developing factory farm landscape in rural Ontario could not be challenged by the Humane Society or any other organization.

\section{The Route to Institutionalization of Animal Welfare Within the Swine Industry}

The agribusiness sector had an unrestricted political path to expand the factory farm model in Ontario as clearly illustrated in the pages of the Hog Production, which was later rebranded the Canadian Pork. The most serious constraints and threats to pig farming arose from the animal's biology and its diet, as well as from market forces especifically the costs of soybeans in the mid-1970s that led to a temporary recession in the pig industry (Canadian Pork, 1973, November, p. 2; Canadian Pork, 1974, August, p.15).

By the late 1970s and early 1980s, with increasing pig production the industry had begun tolerating modest demands from the animal welfare movement. We speculate that this had to do with the increasingly popular appeal of the animal welfare movement's message, the rise of counterculture and environmentalism, and also with the humane movement leadership's ability to negotiate political gains with the agribusiness sector (Beers, 2006). It is also relevant to consider an increasing cultural sensibility towards animals rooted in the 1970s and 1980s; an international phenomenon linked to increased urbanization and absence of customary experiences, especially those starting in childhood, involving violence against animals sanctioned by cultural practices, like farm slaughter, castration without anaesthetics etc. This phenomenon, initially prevalent in the Anglo-American world but has increasingly spread to other parts of the world, including developing countries like Brazil, seems to indicate that once liberated from harsh circumstances of the natural world, human beings prefer not to harm or kill animals (Bulliet, 2005; Lee, 2008; Thomas, 1984).

Besides human nature debates, with the spread of bigger factory farms and slaughterhouses in the last decade, fewer people are in direct contact with the life and death of pigs. This 
certainly has consequences on our empathy for pigs and other animals (White, Dalrymple \& Hume, 2007, p. 2-17; Brisson, 2016, p. 9). Since factory farms only require a limited labor force and animals are very susceptible to diseases, the vast majority of people living in Ontario in the last decades (especially since the 1980s) have never been to places where pigs live and die. The nature of farmers' own interactions with pigs has also changed. Because, farmers need to deal with hundreds or thousands of animals: they are unlikely to treat them like individuals, for example by giving them names which was common in the early $20^{\text {th }}$ century or in earlier times, or like people today treat their pets (Anderson, 2014; Essig, 2015, p. 191; Jones, 2002).

This increasing sensibility towards animals, which paradoxically included factory farms, helps shed light on why the agribusiness sector was now more willing to sit at the table with the humane movement in Ontario. Additionally, bad treatment of animals could also cause bruises and other problems that could influence meat quality. For example, in a 1985 document from the Ontario Ministry of Agriculture and Food, OMAF, which was first known as the Department of Agriculture, H. J. Swatland, a researcher based at the Department of Food Science and Animal \& Poultry Science at the University of Guelph, stated that "wrong practices" in slaughterhouses were affecting the quality of the meat by causing a problem called PSE - a condition in which the pork become Pale, Soft and Exudative making the meat unusually pasty and watery. The problem was caused in part by genetics, but also by "poor slaughter technique". The researcher stated:

Perfectly healthy, normal pigs may produce PSE pork if they are:

Allowed to fight before slaughter,

Herded with an electric prod,

Stressed as a result of poor facilities or handling,

Handled with a pneumatic squeeze (blood pressure is high),

Improperly stunned so that reflex activity is excessive,

Left too long in the scalding tank, (...) (Swatland, 1985, p. 2)

He also offered a recommendation that provided a sneak peek into the violent environment in slaughterhouses and the living conditions of pigs that came from factory farms:

Take a critical look at your slaughter operation. The factors contributing to PSE are often very obvious, such as excessive electrical prodding of animals on the way to stunning or forced uphill exercise (remember that pigs may be quite unused to even mild exercise) (Swatland, 1985, p. 3).

In December 1978, the Animal Welfare Foundation of Canada, chaired by Basil Capes, organized a conference in Ottawa bringing together the humane societies and major agricultural organizations, including the provincial and federal government, to discuss the practices of intensive farming. There were representatives from the following organizations: the Canadian Federation of Agriculture, the Agricultural Institute of Canada, the Canadian 
Veterinary Medical Association, the Canadian Feed Industry Association, the Canadian Council on Animal Care, the Canadian Cattlemen's Association, the Ontario Pork Producers, the Ontario Wildlife Rescue, the Ontario Ministry of Agriculture and Food (Veterinary Services Branch) and Agriculture Canada (Animals'Voice, Winter 1979, p. 1).

The magazine Animals' Voice reveals that "the key speech, from the humane movement's point of view, was presented by Mrs. Ruth Harrison", who by that time was Co-ordinating Executor of Farming, Animals Welfare Advisory Committee for the UK Government. From the conference, it was resolved that,

"a national committee on intensive farming practices" will be established with the responsibility of providing permanent liaison between agricultural associations, government departments and the humane movement as far as intensive livestock practices are concerned (Animals'Voice, Winter 1979, p. 1).

All these negotiations between the humane movement and the agribusiness sector led to the introduction of the Codes of Practice, in 1980, which recommended a series of measures for farmers handling animals. A 1990 report by the Expert Committee on Farm Animal Welfare and Behaviour sheds light on these negotiations:

Since 1980, recommended Canadian Codes of Practice have been written for pigs, special fed-veal calves, ranched foxes, ranched mink, poultry, and dairy cattle. Preparation of these codes has been coordinated by the Canadian Federation of Humane Societies (CFHS). The process has generally begun by the commodity group writing to the CFHS indicating their interest in developing a code and requesting assistance in so doing. The CFHS then requests financial support from the Minister of Agriculture. If the Minister supports their proposal, he then requests the CFHS to establish a broadly based working group to undertake this task. The working group meets as necessary to develop and approve the text which is then edited and printed by Research Program Service of Agriculture Canada (1990 Report of the Expert Committee on Farm Animal Welfare and Behaviour, p. 1, 2).

These Codes illustrated that the humane movement, presumably strengthened by a new social context of higher empathy towards animals, had been successfully persuading the agribusiness sector to address the need of more humane agricultural practices. However, we can infer these developments as a new phase in factory farming, when these more shallow or conservative concerns about animals were incorporated into the agenda to facilitate the very expansion of the model. It therefore appears that the promoters of the factory farm model were in the process of adjusting only minor details to give some appearance of genuine concern about animals to an alienated public that had in fact been happening in Ontario and elsewhere since the 1980s with a view to boost production and productivity.

\section{The Animal Welfare Limits and the Marginalization of Discordant Voices}

To incorporate the conservative animal welfare agenda into the major business of factory farming, it was also necessary to discredit voices that were opposed to industrial livestock 
production or animal agriculture altogether. These voices, represented by a small but growing number of vegetarians and vegans, sometimes identified as animal rights advocates, had been treated as "lunatics", "radicals" or "extremists" by the humane movement, animal welfare scientists and agricultural organizations since the early 1980s. For example, the 1991 report of the chairman of the Ontario Pork Producers' Marketing Board revealed concerns about "extremists", and how animal welfare was becoming a commercial slogan, or a target for advertisement:

Animal Welfare is a top priority for the Board. We are convinced that one of our greatest needs is to educate the public so that extremists views do not spread. To help inform people how well farm animals are actually treated, the Board had two displays this year, one at the CNE and one at the Royal Winter Fair. Both booths featured live sows and young pigs and were very well received by visitors (Goodhand, 1991, p. 3).

In fact, these so-called "extremists" organized isolated protests that involved minor property damage in some cases and attracted media attention since the 1980s (Hughes, 1981, p. 3; Ontario Humane Society, 1980; Animals'Voice, 1981, p. 8; Hughes, 1983, p. 3). However, the main reason is their views that humans do not need animal products to survive and to be healthy, and that the killing of animals for food is an unjustifiable form of violence in modern societies. Such views posed a potential threat to the agribusiness sector. One recent episode that exemplifies how animal rights advocates are still portrayed in a negative light is the charges of criminal mischief brought against a woman in Ontario who went to a locked truck close to a slaughterhouse gate in Burlington to give water to pigs on a hot summer day (Reese, 2015).

It is clear that the concept of "animal welfare" has been domesticated and dominated by scientists and organizations closely linked to the agribusiness sector since the 1980s. One example of such an institution is the Expert Committee on Farm Animal Welfare and Behaviour formed in 1986 as a national advisory body on issues of livestock and poultry welfare made up of 22 members (animal welfare scientists, government officials and livestock producers). This committee successfully convinced the Ontario and federal governments to sponsor research, professorships and curriculum changes in veterinary schools to support animal welfare. One important innovation resulting from the work of this Committee was the creation of the Campbell Center for the Study of Animal Welfare in 1990, at the University of Guelph, "a first for Canada (1990 Report of the Expert Committee on Farm Animal Welfare and Behaviour, p. 10).”

Within these new institutional arrangements, one of the limitations imposed was that death was not generally considered a problem of animal welfare. Only what happens before slaughter matters (Yeates, 2010). Based on this rationale, excluding death or killing is strategic for the agribusiness sector as it allows the sector to marginalize those who oppose animal slaughter, as can be read in the first report of the Expert Committee, published in 1987:

Apart from a small minority whose goal is universal vegetarianism, there is 
actually a broad area of agreement between animal producers and animal welfare advocates. Common goals include sound nutrition, adequate housing, prevention of disease and injury, and minimizing stress. There is a need to examine current husbandry practices in sufficient detail so that practices which promote both welfare and productivity can be recommended, and practices contrary to both welfare and productivity can be eliminated, thus leaving a group of practices needing further study to clarify their effects on the animals. There is also a need to reduce the suspicion, alarm and lack of communication between livestock producers and animal welfare advocates (1987 Report of the Expert Committee on Farm Animal Welfare and Behaviour, p. 3, 4).

This incomplete concept of animal welfare, which excludes the problem of death or killing, is now mainstream, and has led to the strange notion described by the philosopher Tatjana Visak that, we are forbidden from kicking animals, but we are allowed to kill them. In addition, she questions: "If the animal counts morally, however, why do we only have to protect its wellbeing and not its life? (Visak, 2011, p. 13)" In pig production in Ontario, we observe this paradox in the sharp rise of concerns about animal welfare especially since the 1980s. Fewer of these concerns have transformed into significant practical changes in the lives of pigs on factory farms. Conversely, the number of slaughtered animals has increased and this number is only limited by constraints of domestic and international markets.

\section{Conclusions}

It can be posited that a future with fewer sanctuary or companion pigs (and other farm animals) allowed to live a long and good life would protect animals' interests much better than an "ideal animal welfare" system where millions of animals are routinely killed and do not experience their natural lifespan. It can also be argued that what is crucial for pigs and other farm animals, is not their total global population but their quality of life; this is also applicable to human beings to some extent. This research also suggests that, the very existence of factory farms resulted from a historical context in which the food system was highly influenced by the agribusiness sector. Ultimately, whether this model of agriculture with all its impacts on animals and the environment continues or not will heavily depend on political support and public persuasion. It is not a natural or inescapable development.

\section{References}

1987 Report of the Expert Committee on Farm Animal Welfare and Behaviour, Canada. McLaughlin Library, University of Guelph.

1990 Report of the Expert Committee on Farm Animal Welfare and Behaviour, Canada. McLaughlin Library, University of Guelph.

Albarella, U., Dobney, K \& Ervynck, A. (Eds.). (2007). Pigs and Humans: 10,000 Years of Interaction. Oxford, GBR: Oxford University Press, UK.

Alderson, E. (1968, April). Looking at Sow Tie-Ups: Do Tie-Ups Spell “Success or Failure?". Hog Production, 12. McLaughlin Library, University of Guelph. 


\section{Al Macrothink}

Journal of Agricultural Studies

ISSN 2166-0379

2020, Vol. 8, No. 4

Anderson, J. L. (2009). Lard to Lean: Making the Meat-Type Hog in Post-World War II America. In W. Belasco, \& R. Horowitz (Eds.), Food Chains: From Farmyard to Shopping Cart (pp.29-46). Philadelphia: University of Pennsylvania Press.

Anderson, K. (2014). "Hitched Horse, Milked Cow, Killed Pig": Pragmatic Stewardship and the Paradox of Human/Animal Relationships in Southern Ontario, 1900-1920 (unpublished master's thesis). University of Guelph, Canada.

Animals' Voice. (1979, Winter). Can "intensive farming" be humane? p. 1. McLaughlin Library, University of Guelph.

Animals' Voice. (Summer 1981). Ontario Humane Society Annual Report, 1980-81. p. 8. McLaughlin Library, University of Guelph.

Beers, D. L. (2006). For the Prevention of Cruelty: The History and Legacy of Animal Rights Activism in the United States. Athens, $\mathrm{OH}$ : Ohio University Press. https://doi.org/10.1353/book.7001

Bohstedt, G. (1970, May). Stomach Ulcers. Hog Production. McLaughlin Library, University of Guelph.

Bowley, P. M. (2013). A Century of Soybeans: Scientific Research and Mixed Farming in Agricultural Southern Ontario, 1881-1983 (unpublished doctoral dissertation). University of Guelph, Canada.

Boyd, W. (2001). Making Meat: Science, Technology, and American Poultry Production. Technology and Culture, 42(4), 631-664. https://doi.org/10.1353/tech.2001.0150

Brisson, Y. (2014). The Changing Face of the Canadian Hog Industry. Statistics Canada. Retrieved from http://www.statcan.gc.ca/pub/96-325-x/2014001/article/14027-eng.htm

Bulliet, R. (2005). Hunters, Herders and Hamburgers: The Past and Future of Human-Animal Relationships. New York: Columbia University Press.

Canadian Pork. (1973, November). Time for Heavy Culling? 2. McLaughlin Library, University of Guelph.

Canadian Pork. (1974, August). Rocketing Feed Costs This Summer Have Caused Even the Staunchest Hog Producers to Wonder About Their Business. 15. McLaughlin Library, University of Guelph.

DeGrazia, D. (2009). Moral Vegetarianism from a Very Broad Basis. Journal of Moral Philosophy, 6, 143-165. https://doi.org/10.1163/174552409X402313

Essig, M. (2015). Lesser Beasts: A Snout-to-Tail History of the Humble Pig. New York: Basic Books.

Finlay, M. R. (2004). Hogs, Antibiotics, and the Industrial Environments of Postwar Agriculture. In S. R. Schrepfer, \& P. Scranton (Eds.), Industrializing Organisms: Introducing Evolutionary History (pp.237-260). New York and London: Routledge. 
Goodhand, J. (1991). Ontario Pork Producers Marketing Board (Report to the Fiftieth Annual Meeting). p. 3. B191089, Archives of Ontario.

Harrison, R. (1964). Animal Machines: The New Factory Farming Industry. London: Vincent Stuart.

Harrison, R. (2013). Animal Machines (reprinted ed.). Wallingford, UK: CABI. https://doi.org/10.1079/9781780642840.0000

Hog Production. (1967, July). Trying Tying Paid Dividends. 3. McLaughlin Library, University of Guelph.

Hog Production. (1967, October). Space Needs of Pigs. McLaughlin Library, University of Guelph.

Hog Production. (1967, October). Tail Biting. McLaughlin Library, University of Guelph.

Hog Production. (1970, June). How Much Space. 14. McLaughlin Library, University of Guelph.

Horowitz, R. (2004). Making the Chicken of Tomorrow: Reworking Poultry as Commodities and as Creatures, 1945-1990. In S. R. Schrepfer, \& P. Scranton (Eds.), Industrializing Organisms: Introducing Evolutionary History (pp.215-235). New York and London: Routledge.

Hughes, T. I. (1965, June). "Farm or Factory?". The Animals' Voice, 2. McLaughlin Library, University of Guelph.

Hughes, T. I. (1981, Summer) “Lunatic fringe” doesn't help (Editorial). Animals'Voice. p. 3. McLaughlin Library, University of Guelph.

Hughes, T. I. (1983, Spring). There is No Room for Violence in the Humane Movement. Animals'Voice. p. 3. McLaughlin Library, University of Guelph.

Ingram, D. (2013). Beastly Measures: Animal Welfare, Civil Society, and State Policy in Victorian Canada. Journal of Canadian Studies, 43(1), 221-252. https://doi.org/10.3138/jcs.47.1.221

Jones, S. D. (2002). Valuing Animals: Veterinarians and Their Patients in Modern America. Baltimore: Johns Hopkins University Press.

Keddie, P. D., \& Wandel, J. (2001). The "Second Wave": the Expansion of Soybeans Across Southern Ontario, 1951-96. The Great Lakes Geographer, 8(1), 15-30.

Lee, P. Y. (Ed.). (2008). Meat, Modernity, and the Rise of the Slaughterhouse. Lebanon-NH: University Press of New England.

MacLachlan, I. (2008). Humanitarian Reform, Slaughter Technology, and Butcher Resistance in Nineteenth-Century Britain. In P. Y. Lee (Ed.), Meat, Modernity, and the Rise of the Slaughterhouse (pp.107-126). Lebanon-NH: University Press of New England. 


\section{Macrothink}

Journal of Agricultural Studies

ISSN 2166-0379

2020, Vol. 8, No. 4

Matheny, G., \& Chan, K. M. A. (2005). Human Diets and Animal Welfare: The Illogic of the Larder. Journal of Agricultural and Environmental Ethics, 18, 579-594. https://doi.org/10.1007/s10806-005-1805-x

Mayda, C. (2004). Pig Pens, Hog Houses, and Manure Pits: A Century of Change in Hog Production. Material Culture, 36(1), 18-42.

Mizelle, B. (2011). Pig. London, UK: Reaktion Books Ltd.

Ontario Humane Society. (1966a). Intensive Farming. Annual Report. McLaughlin Library, University of Guelph.

Ontario Humane Society. (1966b). Wilful Neglect of Hogs. Annual Report. McLaughlin Library, University of Guelph.

Ontario Humane Society. (1968). Annual Report. McLaughlin Library, University of Guelph.

Ontario Humane Society. (1969). Brief Concerning Bill 74, an Act to Amend the Ontario SPCA Act (1955), Submitted to the Standing Committee on Agriculture and Food of the Legislature of Ontario by the Ontario Society for the Prevention of Cruelty to Animals (The Ontario Humane Society). McLaughlin Library, University of Guelph.

Ontario Humane Society. (1975). Annual Report. McLaughlin Library, University of Guelph.

Ontario Humane Society. (1977). Annual Report. McLaughlin Library, University of Guelph.

Perry, T. W., \& Pickett, R. A. (1967, November). Ulcers in Swine. Hog Production, 10. McLaughlin Library, University of Guelph.

Preece, R. (2008). Sins of the Flesh: A History of Ethical Vegetarian Thought. Vancouver: UBC Press.

Reese, J. (2015). Woman Charged With Criminal Mischief for Giving Water to Thirsty Animals. The Huffington Post. Retrieved from http://www.huffingtonpost.com/jacy-reese/woman-charged-with-crimin_b_8299694.html?ir= India\&adsSiteOverride $=$ in

Robson, G., \& Robson, R. (1972, January). Questions Most Often Asked About Hogs. Hog Production. McLaughlin Library, University of Guelph.

Singer, P. (1975). Animal Liberation: A New Ethics for Our Treatment of Animals. New York: Harper Collins.

Singer, P. (2011). Practical Ethics (3rd ed.). New York: Cambridge University Press. https://doi.org/10.1017/CBO9780511975950

Statistics Canada. (1961). 1961 Census of Agriculture, 9-1 (Ontario).

Stewart, S. M. (1968, July). Summer and Winter Ventilation Problems. Hog Production, 12. McLaughlin Library, University of Guelph.

Swatland, H. J. (1985). An Introduction to the PSE Problem. B500615, Archives of Ontario. 


\section{Macrothink}

Journal of Agricultural Studies

ISSN 2166-0379

2020, Vol. 8, No. 4

Tanner, S. C. (1967, February). "Stress”. Hog Production. McLaughlin Library, University of Guelph.

Thomas, K. (1984). Man and the Natural World: Changing Attitudes in England, 1500-1800. London: Penguin.

Thompson, M. D. (2000). This Little Piggy Went to Market: The Commercialization of Hog Production in Eastern North Carolina from William Shay to Wendell Murphy. Agricultural History, 74(2), 569-584.

Turnbull, J. E., \& Bird, N. A. (1971). Confinement Swine Housing. Canada Department of Agriculture. Publication 1451, 15. McLaughlin Library, University of Guelph.

Visak, T. (2011). Killing Happy Animals: Explorations in Utilitarian Ethics. Zutphen, Netherlands: Woohrmann Print Service.

White, J., Dalrymple, J., \& Hume, D. (2007). The Livestock Industry in Ontario, 1900-2000: A Century of Achievement. Unpublished Report. McLaughlin Library, University of Guelph.

White, S. (2011). From Globalized Pig Breeds to Capitalist Pigs: A Study in Animal Cultures and Evolutionary History. Environmental History, 16(1), 94-120. https://doi.org/10.1093/envhis/emq143

White, S. (2016). [Review of the book Lesser Beasts: A Snout-to-Tail History of the Humble Pig, by Mark Essig]. Agricultural History, 90(1), 121-122. https://doi.org/10.3098/ah.2016.090.1.121

Wiseman, J. (2000). The Pig: A British History (2nd ed.). Worcester, UK: Ebenezer Baylis \& Son Ltd.

Woods, A. (2011). From Cruelty to Welfare: The Emergence of Farm Animal Welfare in Britain, 1964-71. Endeavour, 36(1), 1-22. https://doi.org/10.1016/j.endeavour.2011.10.003

Woods, A. (2012). Rethinking the history of modern agriculture: British pig production, c.1910-65. Twentieth Century British History, 23(2), 165-191. https://doi.org/10.1093/tcbh/hwr010

Yeates, J. W. (2010). Death is a Welfare Issue. Journal of Agricultural and Environmental Ethics, 23, 229-241. https://doi.org/10.1007/s10806-009-9199-9

\section{Copyright Disclaimer}

Copyright for this article is retained by the author(s), with first publication rights granted to the journal.

This is an open-access article distributed under the terms and conditions of the Creative Commons Attribution license (http://creativecommons.org/licenses/by/4.0/). 